\title{
SIMULTANEOUS ASSAYS OF METFORMIN HCL AND GLIBENCLAMIDE MIXTURE USING TWO ANALYTICAL METHODS OF SPECTROPHOTOMETRY
}

\author{
MUCHLISYAM BACHRI
}

Department of Chemistry, Faculty of Pharmacy, Universitas Sumatera Utara, USU Campus, Padang Bulan, Medan, 20155, Indonesia

Email: muchlisyam@usu.ac.id

Received: 09 May 2019, Revised and Accepted: 23 Sep 2019

\begin{abstract}
Objective: Area Under Curve method (AUC) and the Multiple Wavelength Spectrophotometric (MWS) method are practice and simple methods for simultaneous assays of Metformin $\mathrm{HCl}$ and Glibenclamide on the tablet dosage form.

Methods: The AUC method is measured for the absorption spectrum with a concentration $4 \mathrm{mg} / \mathrm{l} \mathrm{Metformin} \mathrm{HCl}$ by calculating the area spectrum at wavelength $230-240 \mathrm{~nm}$ and the absorption spectrum with a concentration $8.7 \mathrm{mg} / \mathrm{l}$ Glibenclamide by calculating the area at wavelength $225-235$ $\mathrm{nm}$. The MWS by determining the absorption spectrum and the five wavelength points for the absorption value at $225 \mathrm{~nm}, 229.4 \mathrm{~nm}, 236.6 \mathrm{~nm}, 233$ $\mathrm{nm}$, and $243 \mathrm{~nm}$ and calculated using matrix operations.

Results: The validation test of the AUC method for Metformin $\mathrm{HCl}$ obtained accuracy $=99.35 \%$, linearity $=0.9881$, precision $=0.39 \%$, LOD $=$ $0.4459 \mathrm{mg} / \mathrm{l}$. LOQ $=1.4864 \mathrm{mg} / \mathrm{l}$ and for Glibenclamide obtained accuracy $=100.79 \%$, linearity $=0.9993, \mathrm{precision}=0.65 \%, \mathrm{LOD}=0.4372 \mathrm{mg} / \mathrm{l}, \mathrm{LOQ}$ $=1.4072 \mathrm{mg} / \mathrm{l}$ and the MWS method for Metformin HCl obtained accuracy $=100.76 \%$, linearity 0.9949 , precision $=0.65 \%$, LOD = 0.9103 mg $/ \mathrm{l}, \mathrm{LOQ}$ $=3.0431 \mathrm{mg} / \mathrm{l}$, and for Glibenclamide with accuracy $=100.07 \%$, linearity $=0.9993$. precision $=0.36 \%, \mathrm{LOD}=0.9205 \mathrm{mg} / \mathrm{l}$. LOQ $=3.0431 \mathrm{mg} / \mathrm{l}$, and appropriate the requirements of ICH guidelines.
\end{abstract}

Conclusion: These Methods successively applied to determine of Metformin $\mathrm{HCl}$ and Glibenclamide mixture in tablet dosage form and fulfill the validation requirements.

Keywords: AUC, Glibenclamide, Metformin HCl, MWS, Spectrophotometry methods, Validation

(C) 2019 The Authors. Published by Innovare Academic Sciences Pvt Ltd. This is an open access article under the CC BY license (http://creativecommons.org/licenses/by/4.0/) DOI: http://dx.doi.org/10.22159/ijap.2019v11i6.34022

\section{INTRODUCTION}

The combination of Metformin HCl (MFM) and Glibenclamide (GBC) is widely used as an antidiabetic drug. MFM is a hypoglycemic group for reduces glucose production in the liver and increases muscle tissue sensitivity and adipose to insulin. The GBC is a hypoglycemic drug and a group of Sulfonylureas and works to stimulate insulin secretion from pancreatic Langerhans $\beta$ cell granules. The combination of MFM and GBC will make absorption ability of GBC is increased because the stimulation of insulin secretion by GBC in response to a meal is essential $[1,2]$.

Determination of MFM and GBC levels in a single form can be carried out by the ultraviolet spectrophotometry method, MFM has maximum absorption at $236 \mathrm{~nm}$ and $229 \mathrm{~nm}$ for GBC and also can be determined by HPLC methods $[3,4]$. The method of simultaneous determination of MFM and GBC with the HPLC method was published in the article using the mobile phase consisting of a mixture of $20 \mathrm{mmol}$ ammonium buffer format at $\mathrm{pH} 3.5$ and acetonitrile, with a ratio of 45:55 v/v. [5].

Various studies on the development of Spectrophotometry methods have been published as examples: UV spectrophotometry methods for simultaneous estimation, Double Divisor Spectra derivative spectrophotometry ratio, and MCR method [6-9].

Some researchers have made a simultaneous determination of MFM and GBC mixture of development of spectrophotometry methods such as a derivative spectrophotometry method, simultaneous equation. The discovery of new course spectrophotometry methods has been validated and appropriate requirements of ICH guidelines and can leave the classic spectrophotometry method for multicomponent analysis of drug [10-13].

The AUC method is a simple, economical, and relatively faster way that has also been developed. Research conducted by Ilango and Kumar (2012) for the determination of Medoxomil and Hydrochlorothiazide levels, and Karajgi's research, et al. (2016) for simultaneous determination of Artemether and Lumefantrine levels in drug preparations provided accurate, precise and selective results. The Area Under Curve method in spectrophotometry was carried out and offered exact, and particular [14-17].

The MWS methods are a spectrophotometry method for the simultaneous determination of the drug mixture by determining the absorption point at various wavelengths whose absorption curves have overlapped and the level calculations performed by a matrix operation [18].

The AUC method is a spectrophotometry method which simultaneously determines MFM and GBC overlapping absorption curves between MFM and GBC, whose absorption measurements are not at maximum absorption, but used in areas that have no maximum spectrum curve but which are carried out in a parabolic spectrum area. This method has a value at two selected wavelengths, $\lambda 1$ and $\lambda 2$. The obtained AUC value is determined by the levels of each drug in the regression equation [14-17]. The MWS spectrophotometry method has a procedure to determine the five points on the overlapped absorption curves of the MFM and GBC are used together, then the absorption is determined and calculated by the matrix equation [18].

The aims of this research are to validation and simultaneous assays of AUC and MWS methods for simultaneous determination of MFM and GBC.

\section{MATERIALS AND METHODS}

\section{Instrumentation and methods}

The U. V. Spectrophotometer (Shimadzu 1800) which combined with a set of Personal Computers (P. C. s) equipped with 2.42 UVProbe software and software with the Minitab®17 application. 99.8 $\%$ Metformin $\mathrm{HCl}, 99.4 \%$ Glibenclamide from Kimia Farma Plant Medan, Sumatera Utara, Indonesia, 100.02\% Metformin $\mathrm{HCl}$ and 99.98\% Glibenclamide (Indonesian Standard) Methanol absolute and 25\% NH4OH, E. Merck, German from Rudang Medan Indonesia. Local Product of Metformin and Glibenclamide by Sanbe, Bandung, Indonesia. 


\section{Preparation of MFM and GBC working solutions}

The working solutions are prepared by dissolving $50.3 \mathrm{mg}$ MFM and $50.4 \mathrm{mg}$ GBC powder, transferred to $50 \mathrm{ml}$ volumetric flasks respectively and dissolved with methanol absolute, then taken $5 \mathrm{ml}$ of MFM and $10 \mathrm{ml}$ of GBC accurately and transferred to $50 \mathrm{ml}$ volumetric flasks respectively, then disappeared with methanol pure to get $50.3 \mathrm{mg} / \mathrm{l} \mathrm{MFM}$ and $100.8 \mathrm{mg} / \mathrm{l} \mathrm{GBC}$, and both of them used as working solutions.

\section{Preparation absorption spectrum}

The working solution is taken $0.8 \mathrm{ml}$ of MFM and $0.9 \mathrm{ml}$ of GBC respectively, and then it's measured at the wavelength of $200-400 \mathrm{~nm}$.

\section{The validation test}

The validation of these methods was performed based on the U. S. Food and Drug Administration (FDA) guidelines for precision, accuracy, linearity, the limit of detection (LOD), Limit of Quantitation (LOQ), linearity and coefficient of variation are validation parameter for spectrophotometry methods [19-21].

\section{Accuracy}

The accuracy method was determined using the standard addition method by preparing a sample with three specific ranges of $80 \%$, $100 \%$, and $120 \%$, with six repetitions. The formula for accuracy:

$$
\% \text { recovery }=\frac{C F-C A}{A C *} \times 100 \%
$$

Note:

$\mathrm{CF}=$ Concentration after addition

$\mathrm{CA}=$ Theoretical concentration before addition

$\mathrm{AC}=$ Concentration of the added standard substances

\section{Precision}

The calculation of the relative standard deviation (RSD) value is used to determine the precision in the validation method. RSD is a formula as follows:

$$
R S D=\frac{S D}{X} \times 100 \%
$$

Note:

$\mathrm{RSD}=$ Relative standard deviation

$\mathrm{SD}=$ Standard deviation

$X=$ Average data.

\section{Linearity}

The linearity of the analytical method in the validation method was determined by calculating the correlation coefficient [19-21].

The regression equation is a formula as follows:

$Y=a x+b$

Notes:

$Y=$ Absorption

$a=$ Slope

$x=$ Concentration $\left(\mathrm{mg} / \mathrm{l}^{-1}\right)$

$b=$ Constant.

\section{Limits of detection (LOD) and limits of quantitative (LOQ)}

According to the absorbance at the analytical wavelength, the LOD and LOQ calculations are performed [19-21].

$$
S D=\sqrt{\frac{\sum y-y_{1}}{n-2}}
$$

$$
\begin{aligned}
& L O D=\frac{3,3 \times \mathrm{SD}}{\text { slope }} \\
& L O Q=\frac{10 \times \mathrm{SD}}{\text { slope }}
\end{aligned}
$$

Note:

$\mathrm{SD}=$ Standard deviation

Slope $=a(y=a x+b)$

\section{Area under curve method (AUC)}

\section{Construction of absorption spectrum of MFM and GBC}

The working solution is carefully taken at $4.0 \mathrm{mg} / \mathrm{l} \mathrm{MFM}$ and 8.7 $\mathrm{mg} / \mathrm{l} \mathrm{GBC}$ concentrations and measured their absorption spectrum respectively and used a U. V. probe 2.42 software to calculate the area values in the area range $230-240 \mathrm{~nm}$ for MFM and 225$235 \mathrm{~nm}$ areas for GBC. The Concentration of Metformin and Glibenclamide can be determined as follows [14-17]:

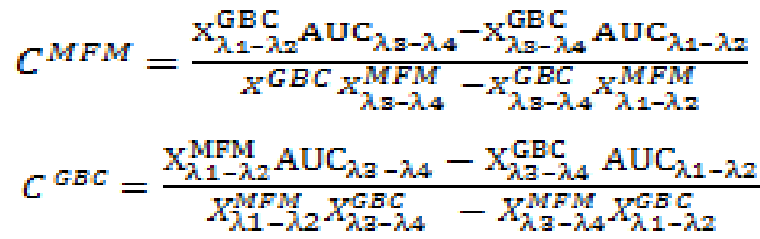

Note:

$\mathrm{C}=$ Concentration

$\mathrm{X}_{\lambda 1-\lambda_{2}}=\mathrm{AUC}_{\lambda_{1}-\lambda_{2}} /$ Concentration in $\mathrm{mg} / \mathrm{l}^{-1}$

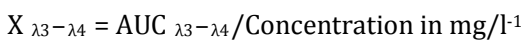

\section{Construction of calibration curve for the AUC method}

The calibration curve can determine by the value of the area in the curve between two selected wavelengths such as $\lambda 1$ and $\lambda 2$ (AUC value), The AUC value of each spectrum in various concentrations is calculated to get the analytical wavelength, then calculated and plotted with varying concentrations to obtain the regression line equation using U. V. Probe 2.42 software $[14,16]$ :

$$
Y=a X+b
$$

Note:

$$
\begin{aligned}
& \mathrm{Y}=\mathrm{AUC} \text { value } \\
& \mathrm{a}=\text { intercept } \\
& \mathrm{b}=\text { regression coefficient }
\end{aligned}
$$

\section{Multiple wavelength spectrophotometry methods}

\section{Construction of spectrum selection point}

The working solution is construction to $4.0 \mathrm{mg} / \mathrm{l}^{-1} \mathrm{MFM}$ and 8.7 $\mathrm{mg} / \mathrm{l}^{-1}$ GBC concentrations, and these solution's absorption measured at 200-400 nm wavelength. Furthermore, the absorption spectrum overlapped Then searches five points as the wavelength to use. Wavelength selection is taken from the absorption spectrum of components, the absorption measured at predetermined multiple wavelengths. Both compound's absorption is determined using the matrix equation method, which operated in the concentration and absorption data of each compound at each wavelength measurement

\section{Determination of MFM and GBC absorption curves}

Carefully weighed $4.0 \mathrm{mg}$ MFM (Indonesian Standard) and $8.7 \mathrm{mg}$ of GBC (Indonesian Standard) and then transfer into the $10.0 \mathrm{ml}$ flask, diluted with methanol to obtain a solution with a concentration of $4.0 \mathrm{mg} / \mathrm{l}^{-1} \mathrm{MFM}$ and of $8.7 \mathrm{mg} / \mathrm{l}^{-1} \mathrm{GBC}$, then the two solutions are measured for each at a wavelength of $200-400 \mathrm{~nm}$. Furthermore, the two curves are overlapped and determined the five points. 


\section{Assay procedures for a tablet by AUC and MWS}

Twenty tablets were weighed and finely powdered. The powder obtained was sufficiently considered in such a way to contain 50 $\mathrm{mg}$ of MFM and transferred to a $50 \mathrm{ml}$ volumetric flask, dissolved with methanol. Then, pipette $0.1 \mathrm{ml}$ sample solution and added $4.3 \mathrm{ml}(433.44 \mu \mathrm{g})$ of GBC working solution for standard addition.

The measured absorption spectrum is created in the area of 230$240 \mathrm{~nm}$ for MFM and $235-245 \mathrm{~nm}$ for GBC at the AUC method. Level calculations are done using the regression equation [1417]

The MWS methods are the methods for measurement of MFM and GBC mixture based on five-point absorption from the overlapping curve of raw material. The content of each component in the mix is calculated based on the absorption capacity of drug samples (Ac) and the absorption value and obtained from measurements of predetermined wavelengths, and component levels obtained using a matrix equation [18].

$$
\left.[c]=[[a] x[a 1]]^{-1} x[a] x A c\right]
$$

Note:

$\begin{array}{ll}{[\mathrm{c}]} & =\text { components concentration of mixture } \\ {[\mathrm{a} 1]} & =\text { transpose absorption matrix of mixed compounds } \\ \{\mathrm{a}\} & =\text { matrix of the compound mixture absorption } \\ {[[a] x[a 1]]^{-1}} & =\text { matrix inverses multiplied by the transpose } \\ {[\mathrm{Ac}]} & \text { absorption matrix of compound mixture } \\ & =\text { matrix of sample absorption value }\end{array}$

\section{RESULTS AND DISCUSSION}

The principle of development method on U. V. spectrophotometry

The Principle of the method of molecular absorption in U. V. spectrophotometry has been widely used for the determination of drug components in pharmaceutical preparations. This method can be used for pharmaceutical analysis, which has a spectrum matrix constraint of the active drug, overlapped and making it difficult as the simultaneous determination of the drug mixture [3-4].

\section{Absorption spectrum of MFM and GBC}

Determination of maximum absorption spectrum of Metformin and Glibenclamide was making in the wavelength range of $200-400 \mathrm{~nm}$. The results obtained that the qualitative absorption spectrum of $4.1 \mathrm{mg} / \mathrm{l}^{-1}$ Metformin at the $235.6 \mathrm{~nm}\left(\mathrm{fig} .1\right.$ ) and $8.7 \mathrm{mg} / \mathrm{l}^{-1}$ Glibenclamide at $228.2 \mathrm{~nm}$ (fig. 2).

The maximum absorption of MFM and GBC at $235.6 \mathrm{~nm}$ and 228.2 $\mathrm{nm}$ is qualified because that Moffat (2011) wrote that the maximum wavelength of MFM is located at $236 \mathrm{~nm}, \mathrm{GBC}$ was located at $225 \mathrm{~nm}$ as methanol is a solvent. Based on Indonesian Pharmacopeia that the difference in the maximum wavelength of each MFM and GBC was no less and no more than $5 \mathrm{~nm}[3,4]$. It means that the maximum wavelength of each component is qualified.

\section{Validation methods}

The result from the production of validation test must be achieved for chemical analysis activities. The validation test result is described as linearity, LOD, LOQ, $\mathrm{R}^{2}$. accuracy, and precision (table 1).

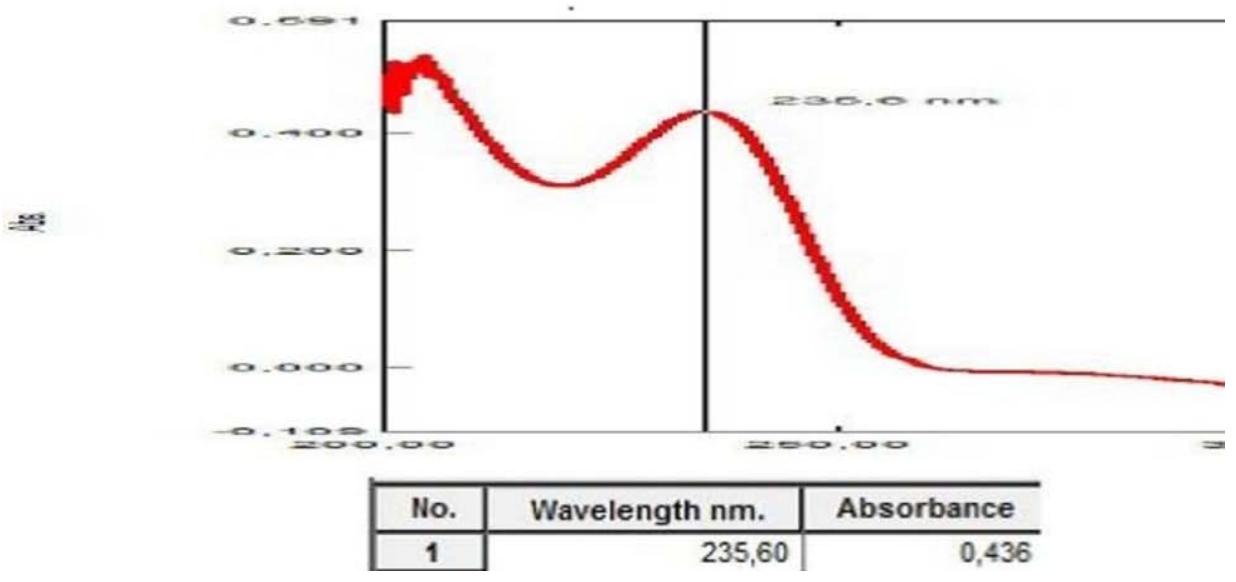

Fig. 1: MFM absorption spectra

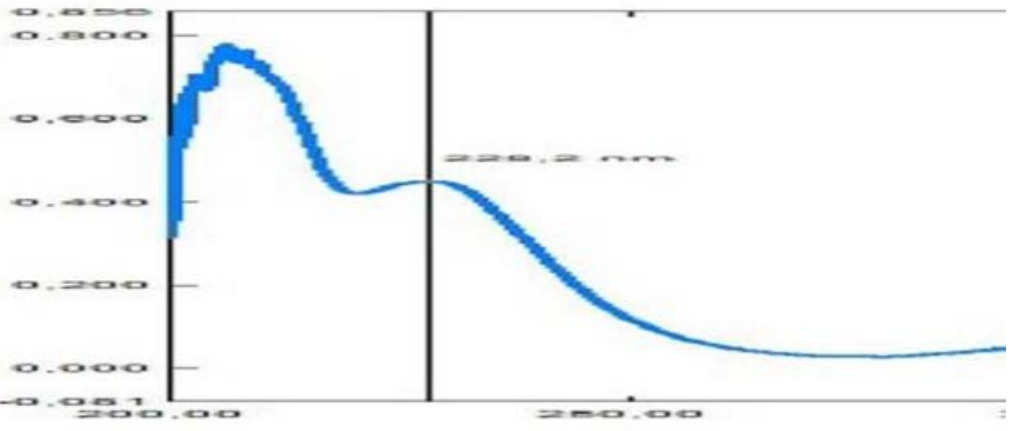

\begin{tabular}{|c|r|r|}
\hline No. & Wavelength $\mathrm{nm}$. & Absorbance \\
\hline 1 & 228,20 & 0,449 \\
\hline
\end{tabular}

Fig. 2: GBC absorption spectra 
Table 1: Validation of the AUC method and MWS method

\begin{tabular}{llll}
\hline Parameter & MFM & GBC & AUC \\
\cline { 2 - 4 } & AUC & MWS & Methanol \\
\hline Solvent & Methanol & 0.9949 & 0.9103 \\
\hline Linearity (\%) & 0.9881 & 0.9993 & 3.0344 \\
LOD (mg/l) & 0.4459 & 0.4372 & 0.9987 \\
LOQ (mg/l) & 1.4864 & 1.4072 & 0.9946 \\
R & 0.9881 & 0.9993 & 100.76. \\
Accuracy(\%) & 99.35 & 103.16 & 0.65 \\
Precision (\%) & 0.39 & $0.26 \%$ & 0.9993 \\
\hline
\end{tabular}

It can be stated that the AUC and MWS method have excellent accuracy and precision, besides that all carried out measurements are in the 0.2-0.6 absorption area which means that the sample measurements are also above the detection limit and the quantitation limit because all parameters of validation test have according to the validation requirements of ICH 2015. It means that both of these methods have appropriated the validation requirements [15-17].

\section{Result of AUC methods and MWS methods for sample}

The spectrum absorption curve of sample for the market product

The curve of the spectrum absorption from a mixed sample of 250 mg Metformin $\mathrm{HCl}$ and $1.25 \mathrm{mg}$ Glibenclamide on market products can be seen in the fig. 3 below.

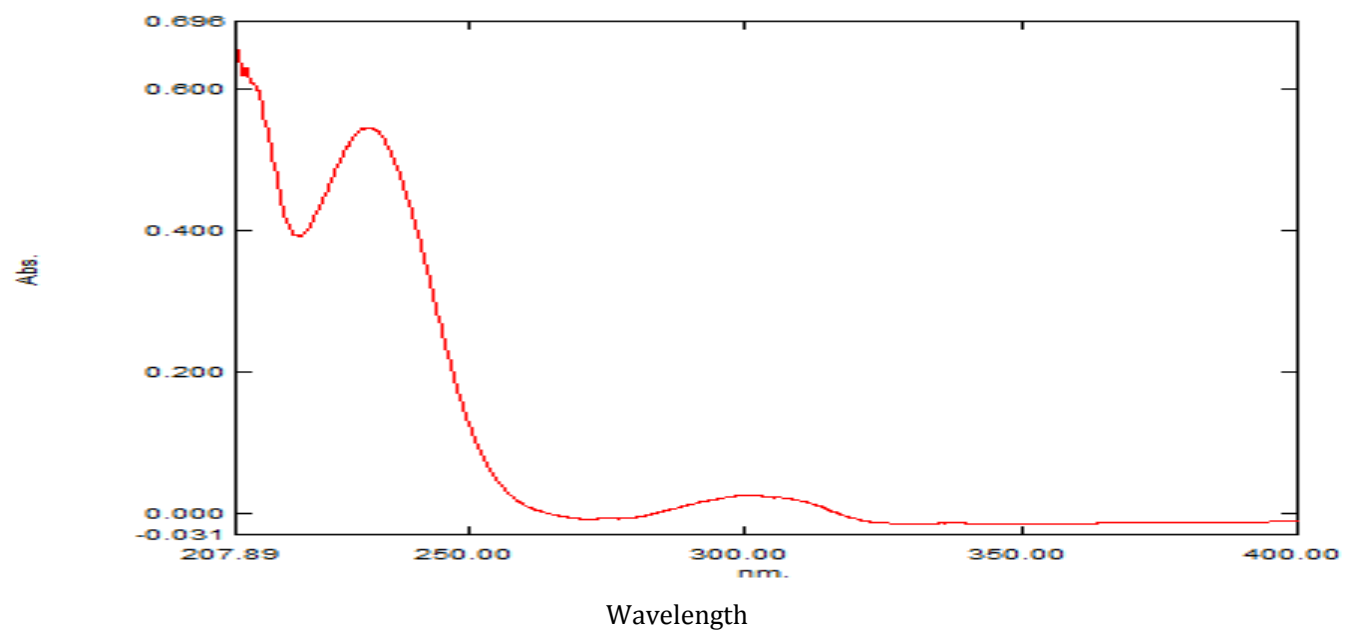

Fig. 3: The curve absorption spectrum of sample from market products

Based on the fig. 3 above, it can be seen that the concentration of $\mathrm{GBC}$ in the mixture is minimal. Based on the validation method for LOQ results of the AUC method has obtained LOQ $=3.0344$ $\mathrm{mg} / \mathrm{l}$ While the MWS method is $\mathrm{LOQ}=3.0431 \mathrm{mg} / \mathrm{l}$ and it is true that content of GBC in tablets sample containing $50 \mathrm{mg}$ of MFM, It's small below LOQ which is $0.2499 \mathrm{mg}$. According to the law of lambert beer, this naturally produces in a low GBC concentration, namely $0.0199 \mathrm{mg} / \mathrm{l}$ while the GBC concentration is according to the level of MFM. So the GBC working solution was added $8.6801 \mathrm{mg} / \mathrm{l}$ which total was added $433.44 \mu \mathrm{g}$ in 50 ml sample solution. So, using the AUC and MWS methods, the content of glowing levels in the sample can be known.

\section{Overlapped absorption spectrum for AUC method}

The AUC method begins by calculating the AUC value in the spectrum in the wavelength range of $227 \mathrm{~nm}-248 \mathrm{~nm}$ with concentrations of (2.3. 4. 5.6) $\mathrm{mg} / \mathrm{l}$ for MFM and wavelength range $225 \mathrm{~nm}-236 \mathrm{~nm}$ with a level of (4.7. 6.7. 8.7. 10.7. 12.7) $\mathrm{mg} / \mathrm{l}$ for GBC the range of $\lambda$ (wavelength) selected to give the best linearity relationship between the AUC and Concentration (fig. 4) as indicated by the value of the correlation coefficient $(r \leq 1)$ and can be seen at table $2[15,16]$.

Table 2: Wavelength of analysis for metformin and glibenclamide

\begin{tabular}{|c|c|c|c|}
\hline Component & Wavelength (nm) & $\Delta \lambda$ & Linierity \\
\hline \multirow[t]{4}{*}{ Metformin } & G227-231 & 5 & 0.9688 \\
\hline & $234-238$ & 5 & 0.9797 \\
\hline & $230-240$ & 10 & 0.9881 \\
\hline & $231-241$ & 10 & 0.9880 \\
\hline \multirow[t]{4}{*}{ Glibenclamide } & $227-231$ & 5 & 0.9757 \\
\hline & $228-232$ & 5 & 0.9934 \\
\hline & $225-235$ & 10 & 0.9949 \\
\hline & $226-236$ & 10 & 0.9934 \\
\hline
\end{tabular}

Based on table 2 shows that the excellent wavelength range is (230240) $\mathrm{nm}$ for GBC have a good the value of the correlation coefficient, so the selected wavelengths to determine MFM and GBC by spectrophotometry UV with AUC method were 230-240 nm and $225-235 \mathrm{~nm}$, respectively. It concludes that there is no overlapping AUC of each wavelength ranges both for MFM (230-240) nm and 
GBC (225-235) $\mathrm{nm}$ and affecting one to another. The absorption value that appropriates the requirements is obtained with the wavelength range. That's mean AUC method can be used to determine simultaneously the drug content, which consisting of more than one component $[15,17]$.

The determination of the AUC in the tablet market production is carried wavelength (230-240) nm for MFM and (225-235) nm for $\mathrm{GBC}$ with calculations based on the following formula:

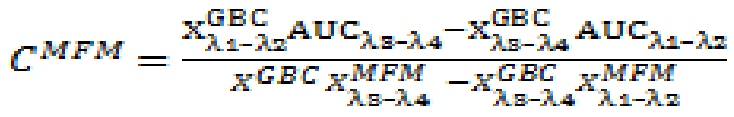

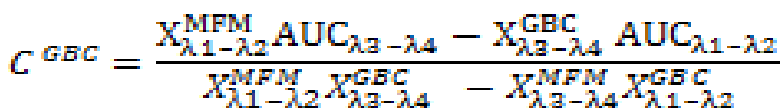

Note:

$\mathrm{C}=$ Concentration

$\mathrm{X}_{\lambda 1-\lambda_{2}}=\mathrm{AUC}_{\lambda 1-\lambda_{2}} /$ Concentration in $\mathrm{mg} / \mathrm{l}^{-1}$

$\mathrm{X}_{\lambda 3-\lambda 4}=\mathrm{AUC} \lambda_{3}-\lambda_{4} /$ Concentration in $\mathrm{mg} / \mathrm{l}^{-1}$

Based on the calculation above, the AUC values are obtained, which result in table 3 for MFM and table 4 for GBC below.

Table 3: AUC value of MFM

\begin{tabular}{lll}
\hline No. & Concentration $(\mu \mathrm{g} / \mathrm{ml})$ & AUC $(\mathrm{Y})$ \\
\hline 1 & 0.0000 & 0.0000 \\
2 & 2.0 & 0.1840 \\
3 & 3.0 & 0.2880 \\
4 & 4.0 & 0.3130 \\
5 & 5.0 & 0.3760 \\
6 & 6.0 & 0.4680 \\
\hline
\end{tabular}

Table 4: AUC value of GBC

\begin{tabular}{lll}
\hline No. & Concentration $(\mu \mathrm{g} / \mathrm{ml})$ & AUC $(\mathbf{Y})$ \\
\hline 1 & 0.0000 & 0.0000 \\
2 & 4.7 & 0.1170 \\
3 & 6.7 & 0.1850 \\
4 & 8.7 & 0.2430 \\
5 & 10.7 & 0.2930 \\
6 & 12.7 & 0.3860 \\
\hline
\end{tabular}

Based on the AUC value in table 3 and table 4. then each regression equation can be calculated whose results can be shown in table 5 for MFM and table 6 for GBC.

Table 5: Calculation of regression equations on MFM

\begin{tabular}{|c|c|c|c|c|c|}
\hline No. & $\mathbf{X}$ & $\mathbf{Y}$ & $\mathbf{X Y}$ & $\mathbf{X}^{2}$ & $\mathbf{Y}^{2}$ \\
\hline 1. & 0.0000 & 0.00000 & 0.00000 & 0.00000 & 0.0000000000 \\
\hline 2. & 2.0 & 0.1840 & 0.368 & 4 & 0.033856 \\
\hline 3. & 3.0 & 0.2880 & 0.864 & 9 & 0.082944 \\
\hline 4. & 4.0 & 0.3130 & 1.252 & 16 & 0.097969 \\
\hline 5. & 5.0 & 0.3760 & 1.88 & 25 & 0.141376 \\
\hline \multirow[t]{3}{*}{6.} & 6.0 & 0.4680 & 2.808 & 36 & 0.219024 \\
\hline & $\Sigma \mathrm{X}=20$ & $\Sigma Y=1.629$ & $\Sigma X Y=1.1953$ & $\Sigma \mathrm{X}^{2}=90$ & $\Sigma \mathrm{Y}^{2}=0.575169$ \\
\hline & $\bar{X}=3.3333$ & $\bar{Y}=0.2715$ & & & \\
\hline
\end{tabular}

Table 6: Calculation of regression equations on GBG

\begin{tabular}{llllll}
\hline No. & $\mathbf{X}$ & $\mathbf{Y}$ & $\mathbf{X Y}$ & $\mathbf{X}^{2}$ & $\mathbf{Y}^{2}$ \\
\hline 1. & 0.0000 & 0.00000 & 0.00000 & 0.00000 & 0.0000000000 \\
2. & 4.7 & 0.1170 & 0.5499 & 4.0900 & 0.013689 \\
3. & 6.7 & 0.1850 & 1.2395 & 75.6900 & 0.034225 \\
4. & 8.7 & 0.2430 & 2.1141 & 114.4900 & 0.059049 \\
5. & 10.7 & 0.2930 & 3.1351 & 161.2900 & 0.085849 \\
6. & 12.7 & 0.3860 & 4.9022 & $\Sigma X^{2}=418.45$ & \\
& $\Sigma X=43.5$ & $\Sigma Y=1.224$ & $\Sigma X Y=11.9407$ & & \\
& $\bar{X}=7.25$ & $\bar{Y}=0.204$ & & & \\
\hline
\end{tabular}

Baesd on table 5 and table 6 can be calculated the regression equation by formula (19)

$$
Y=a X+b
$$

Note:

$\mathrm{Y}=\mathrm{AUC}$ value

$\mathrm{a}=$ intercept $\mathrm{b}=$ regression coefficient

Based on calculations from the above formula, the regression equation for MFM and GBC is obtained $\mathrm{y}=0.074 \mathrm{x}+0.022$ and $\mathrm{y}=$ $0.029 \mathrm{x}-0.011$. The calculation of the sample is carried out with replications six times followed by statistical calculations so that the average level is obtained in table 7 , table 8 and table 9. 
Table 7: The metformin $\mathrm{HCl}$ levels on the market product samples

\begin{tabular}{llll}
\hline No & Weight of MFM in the sample (mg) & Weight of the study results (mg) & Percentage of measure result (\%) \\
\hline 1 & 50.06 & 51.12 & $101.37 \%$ \\
2 & 50.09 & 52.00 & $103.05 \%$ \\
3 & 50.11 & 52.12 & $103.24 \%$ \\
4 & 50.12 & 52.25 & $103.47 \%$ \\
5 & 50.14 & 52.75 & $104.40 \%$ \\
6 & 50.15 & 52.62 & $104.10 \%$ \\
\hline
\end{tabular}

Table 8: The glibenclamide levels on the market product samples

\begin{tabular}{llll}
\hline No & $\begin{array}{l}\text { Weight of GBC in the sample } \\
\text { (mg) }\end{array}$ & $\begin{array}{l}\text { Addition weights of raw GBC to the } \\
\text { sample (mg) }\end{array}$ & $\begin{array}{l}\text { Weight of the study results } \\
\text { (mg) }\end{array}$ \\
\hline 1 & 0.2498 & 108.50 & $\begin{array}{l}\text { Percentage of measure } \\
\text { result (\%) }\end{array}$ \\
2 & 0.2505 & 108.62 & 108.75 \\
3 & 0.2507 & 108.50 & 108.87 \\
4 & 0.2511 & 108.50 & 109.00 \\
5 & 0.2515 & 108.62 & 108.75 \\
6 & 0.2526 & 108.62 & 108.87 \\
\hline
\end{tabular}

Table 9: Statistical calculation of MFM and GBC on the market product

\begin{tabular}{lllll}
\hline No & Component of drug & Statistical calculation & Content in etiquette & Level requirements \\
\hline 1 & MFM & $(103.27 \pm 1.7521) \%$ & $250 \mathrm{mg}$ & $(95-105) \%$ \\
2 & GBC & $(98.02 \pm 2.0404) \%$ & $1.25 \mathrm{mg}$ & $(95-105) \%$ \\
\hline
\end{tabular}

Based on table 9 above, after statistical calculation of MFM and GBC in the market production mixture, the levels were $(103.27 \pm 1.7521) \%$ for MFM and (98.02 \pm 2.0404$) \%$ for GBC to meet the requirements for tablet dosage according to Indonesian Pharmacopoeia Edition V is (95-105)\%. It means that the AUC method can be used to simultaneous determine the mixture of MFM and GBC in a tablet.

\section{Result of five absorption points for MWS methods}

The simultaneous determination of MFM and GBC is combined of two spectra, to make a five of wavelength points (for analysis of MFM and GBC mixture). The five used to measure the absorption of each standard solution MFM and GBC was obtained (fig. 4).

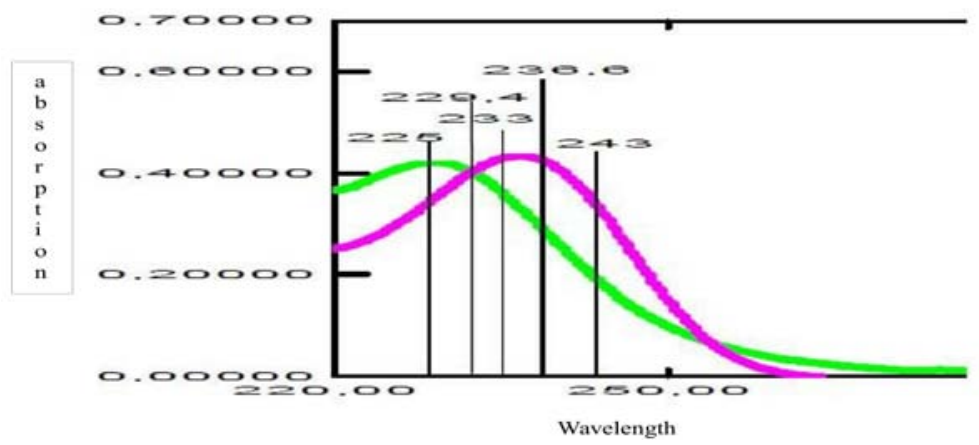

Fig. 4: Five-wavelength analysis used in the multiple wavelengths method

After measuring the absorption of each solution by various concentrations at the five wavelengths are obtained that five wavelengths used is $225 \mathrm{~nm}$, at a wavelength of MFM and GBC have begun to provide absorption. The wavelength of 229.4 is the maximum absorption GBC, and wavelength of $233 \mathrm{~nm}$ is the point of intersection of MFM and GBC, the wavelength of $236.6 \mathrm{~nm}$ is the maximum wavelength of MFM, and a wavelength of $243 \mathrm{~nm}$, either MFM or GBC absorption begins to decrease. The obtained absorption data is used to establish the levels of MFM and GBC in the mixture with matrix calculation.

\section{Results of determination of absorption at five wavelengths}

Absorption value is the ability of the absorption of a compound to absorb from a mixture of compounds at the selected wavelength. The determination of the absorption value is done by measuring the absorption of each solution of MFM and GBC at a wavelength of 225 $\mathrm{nm} ; 229.4 \mathrm{~nm} ; 233 \mathrm{~nm} ; 236.6 \mathrm{~nm}$; and $243 \mathrm{~nm}$. The measurements result of MFM and GBC uptake can be seen in table 10 .
The selection of absorption values (a) can be determined based on the calculated r-value. The estimated r-value is compared with the r-value of the table with a confidence level of $95 \%$ with df four, which is 0.8114 . Based on table 10 and table 11 above, the value of $r$ count metformin and glibenclamide are higher than the value of $r$ table. It means that the equation has excellent linearity because the value of $r$ count is $\leq 1$.

\section{Simultaneous determination results of MFM and GBC with the MWS method}

The market preparations contain MFM $250 \mathrm{mg}$ and GBC $1.25 \mathrm{mg}$. With a ratio of 1: 200 so that the GBC level is challenging to analyze. To overcome this, add the GBC working solution so that measurements can be made with six repetitions, with the aim that the data obtained is more accurate. Then the absorption is measured at the five wavelengths of 225 $\mathrm{nm} ; 229.4 \mathrm{~nm} ; 233 \mathrm{~nm} ; 236.6 \mathrm{~nm}$ and $243 \mathrm{~nm}$. The absorption data of the mixed samples of MFM and GBC samples were obtained, then carried out by calculating the matrix so that the level and percentage of the coefficient of variation can be seen in table 12 below. 
Table 10: Result of absorption value of MFM

\begin{tabular}{|c|c|c|c|c|c|}
\hline $\begin{array}{l}\text { Concentration } \\
(\mu \mathrm{g} / \mathrm{ml})\end{array}$ & $\begin{array}{l}\text { Wavelength } \\
225 \mathrm{~nm}\end{array}$ & $\begin{array}{l}\text { Wavelength } \\
229.4 \mathrm{~nm}\end{array}$ & $\begin{array}{l}\text { Wavelength } \\
233 \mathrm{~nm}\end{array}$ & $\begin{array}{l}\text { Wavelength } \\
236,6 \mathrm{~nm}\end{array}$ & $\begin{array}{l}\text { Wavelength } \\
243 \mathrm{~nm}\end{array}$ \\
\hline 0.0 & 0.0000 & 0.0000 & 0.0000 & 0.00000 & 0.0000 \\
\hline 2 & 0.1268 & 0.1834 & 0.2278 & 0.24738 & 0.1936 \\
\hline 3 & 0.1904 & 0.2600 & 0.3140 & 0.34029 & 0.2742 \\
\hline 4 & 0.2118 & 0.3167 & 0.4017 & 0.44580 & $0.3586 \backslash$ \\
\hline 5 & 0.2788 & 0.4054 & 0.5092 & 0.56339 & 0.4579 \\
\hline \multirow[t]{3}{*}{6} & 0.3338 & 0.4877 & 0.6142 & 0.67867 & 0.5494 \\
\hline & $a=0.062$ & $a=0.084$ & $a=0.101$ & $a=0.110$ & $a=0.075$ \\
\hline & $r=0.9995$ & $r=0.9981$ & $r=0.9990$ & $r=0.9993$ & $r=0.9996$ \\
\hline
\end{tabular}

Table 11: Result of absorption value of GBC

\begin{tabular}{|c|c|c|c|c|c|}
\hline $\begin{array}{l}\text { C } \\
(\mu g / m l)\end{array}$ & $\begin{array}{l}\text { Wavelength } \\
225 \mathrm{~nm}\end{array}$ & $\begin{array}{l}\text { Wavelength } \\
229.4 \mathrm{~nm}\end{array}$ & $\begin{array}{l}\text { Wavelength } \\
233 \mathrm{~nm}\end{array}$ & $\begin{array}{l}\text { Wavelength } \\
236,6 \mathrm{~nm}\end{array}$ & $\begin{array}{l}\text { Wavelength } \\
243 \mathrm{~nm}\end{array}$ \\
\hline 0.0 & 0.0000 & 0.0000 & 0.0000 & 0.0000 & 0.0000 \\
\hline 4.7 & 0.2385 & 0.2448 & 0.2290 & 0.1927 & 0.1199 \\
\hline 6,7 & 0.3290 & 0.3420 & 0.3220 & 0.2713 & 0.1661 \\
\hline 8.7 & 0.4416 & 0.4483 & 0.4180 & 0.3521 & 0.2207 \\
\hline 10.7 & 0.5146 & 0.5351 & 0.5036 & 0.4259 & 0.2664 \\
\hline \multirow[t]{3}{*}{12,7} & 0.6384 & 0.6669 & 0.6281 & 0.5291 & 0.3219 \\
\hline & $a=0.052$ & $a=0.051$ & $a=0.041$ & $a=0.048$ & $a=0.020$ \\
\hline & $r=0.9991$ & $\mathrm{r}=0.9992$ & $\mathrm{r}=0.9992$ & $r=0.9993$ & $r=0.9997$ \\
\hline
\end{tabular}

Table 12: Result of matrix calculation of MFM and GBC by MWS methods

\begin{tabular}{|c|c|c|c|c|c|c|}
\hline \multirow[b]{2}{*}{ No. } & \multicolumn{3}{|l|}{ MFM } & \multicolumn{3}{|l|}{ GBC } \\
\hline & $\begin{array}{l}\text { The concentra-tion of } \\
\text { matrix calculations } \\
(\mu \mathrm{g} / \mathrm{ml})\end{array}$ & $\begin{array}{l}\text { The concentra-tion } \\
\text { of weighing results } \\
(\mu \mathrm{g} / \mathrm{ml})\end{array}$ & $\begin{array}{l}\text { Percentage of } \\
\text { Level (\%) }\end{array}$ & $\begin{array}{l}\text { The concentra-tion of } \\
\text { matrix calculations } \\
(\mu \mathrm{g} / \mathrm{ml})\end{array}$ & $\begin{array}{l}\text { The concentra-tion } \\
\text { of weighing results } \\
(\mu \mathrm{g} / \mathrm{ml})\end{array}$ & $\begin{array}{l}\text { Percentage of } \\
\text { level }(\%)\end{array}$ \\
\hline 1 & 4.07517 & 4.0054 & 100.99 & 8.70025 & 0.02 & 100.24 \\
\hline 2 & 4.22861 & 4.0183 & 104.46 & 8.70033 & 0.02 & 100.63 \\
\hline 3 & 4.23732 & 4.0247 & 104.51 & 8.70097 & 0.02 & 103.84 \\
\hline 4 & 4.24082 & 4.0248 & 104.59 & 8.70018 & 0.02 & 99.90 \\
\hline 5 & 4.04323 & 4.0377 & 99.40 & 8.69972 & 0.02 & 97.61 \\
\hline \multirow[t]{3}{*}{6} & 4.22542 & 3.9924 & 105.06 & 8.66894 & 0.02 & 98.24 \\
\hline & \multicolumn{2}{|c|}{ Average } & 103.16 & \multicolumn{2}{|c|}{ Average } & 100.07 \\
\hline & \multicolumn{2}{|c|}{ Coefficient of variation (\%) } & 0.2628 & \multicolumn{2}{|c|}{ Coefficient of variation (\%) } & 0.3641 \\
\hline
\end{tabular}

Based on table 12 above, that MFM and GBC levels in market products meet the requirements according to Indonesian Pharmacopoeia Edition V (2014), namely for tablet preparations containing MFM and GBC not less than $90 \%$ and no more than $110 \%$ of the amount indicated on etiquette. It means that the MWS method can be used for simultaneous determination of MFM and GBC.
The result of the application of AUC and MWS methods for MFM and GBC

The result of simultaneous determination from the MWS method and the AUC method for MFM and GBC levels has been calculated (table 2).

Table 2: Statistic calculation of MFM and GBC in mixture formula

\begin{tabular}{llll}
\hline Component & AUC & & MWS \\
\cline { 2 - 4 } & MFM & GBC & MFM \\
\hline Self-made Product (\%) & $100.38 \pm 0.97$ & $100.23 \pm 1.52$ & $100.02 \pm 0.29$ \\
Local Product (\%) & 103.27 & 98.02 & 103.16 \\
Coefficient Variation (\%) & 1.75 & 2.04 & 0.26 \\
Range of Level (\%) & $90-110$ & $90-110$ & $98.28 \pm 1.78$ \\
\hline
\end{tabular}

The result of the statistical calculation of this method was not significant, although with a different work procedure. Both ways have given MFM and GBC levels in laboratory self-made and local products, and it's appropriate the requirements according to Indonesian Pharmacopoeia edition V (2014). It means that AUC methods and MWS methods have good accuracy because they are in the range of $90 \%-110 \%$ and also have excellent precision because the percentage of coefficient variation of MFM and GBC are $<2 \%$ [15-17].

\section{CONCLUSION}

The Area Under Curve method and Multiple Wavelength method can simultaneous assays of Metformin and Glibenclamide mixture in methanol solvent with overlapping spectra, and have a functional recovery and accuracy makes them applicable in quality control laboratories and were validated according to ICH guidelines for simultaneous assays of Metformin and Glibenclamide in laboratory self-made and local Product.

Therefore the Area Under Curve method and Multiple Wavelength methods have successfully applied the simultaneous determination of Metformin and Glibenclamide on the pharmaceutical formulation.

\section{ACKNOWLEDGMENT}

The author wishes to thank for Prof. Dr. Masfria, MS., Dean of Faculty Pharmacy Universitas Sumatera Utara for laboratory facilities, also Widia Saswita Siregar and Rona Delsinta Panjaitan, the student of 
undergraduate at Pharmaceutical Chemistry laboratory, Department of Chemistry, Faculty of Pharmacy, Universitas Sumatera Utara for all contributions on technical help to the work reported in this manuscript.

\section{CONFLICT OF INTERESTS}

I declare that there is no conflict of interest

\section{AUTHORS CONTRIBUTIONS}

All the authors have contributed equally

\section{REFERENCES}

1. Gunawan SG. Pharmacology and therapy. $5^{\text {th }}$ ed. Jakarta: Balai Publisher; 2005.

2. Finkel R, Cubeddu LX, Clark MA. Insulin and oral hypoglycemic drugs, In: Lippincott's Illustrated reviews: Pharmacology. $4^{\text {th }}$ ed. Florida: Lippincott Williams and Wilkin; 2009.

3. Moffat AC, Osselton MD, Widdop B, Galichet LY. Clarke's analysis of drugs and poisons. $4^{\text {th }}$ ed. London: Pharmaceutical Press; 2011.

4. Government of Indonesia. Indonesian Pharmacopoeia. $5^{\text {th }}$ ed. Jakarta: Indonesian Health Ministry; 2014.

5. Gedawy A, Al-Salami H, Dass CR. Development and validation of a new analytical HPLC method for simultaneous determination of the antidiabetic drugs, metformin, and gliclazide. J Food Drug Anal 2019;27:315-22.

6. Chaudhary J, Jain A, Saini V. Simultaneous estimation of multicomponent formulations UV-visible spectroscopy: an overview. IRJP 2011;2:81-3.

7. Adriani F, Bachri M, Sinaga SM. Development and validation of double divisor ratio spectra derivative spectrophotometry method for ternary mixture of guaifenesin, dextromethorphan $\mathrm{hbr}$, and diphenhydramine hcl in tablet dosage form. AJCPR 2018;11:1-3.

8. Muchlisyam, Sudarmi, Caroline C. Mean centering of ratio spectra method for the analysis of theophylline and ephedrine hcl mixture in tablet. AJCPR 2018;11:218-23.

9. Muchlisyam, Pardede TR, Satiawan R. Determination of simultaneous sulfamethoxazole and trimethoprim by ultraviolet spectrophotometry with mean centering of ratio spectra. Asian J Pharm Clin Res 2018;11 Special Issue 1:62-9.
10. Ganesh K, Akash G, Preeti K. Simultaneous determination of metformin and glibenclamide by ultraviolet spectrophotometry. Int Res J Pharm 2018;9:211-4.

11. Chavhan BR, Patil PB, Bavaskar SR, Barhate SD. Development and validation of analytical method for simultaneous estimation of glibenclamide and metformin hcl in bulk and tablets using u. v.-visible spectroscopy. WJPR 2015;4:1257-66.

12. Patil SS, Bonde CG. Development and validation of analytical method for simultaneous estimation of glibenclamide and metformin hcl in bulk and tablets using u. v.-visible spectroscopy. Int J ChemTech Res 2009;1:905-9.

13. Umadevi N, Mounika CH, Babu IS. Spectrophotometric method development and validation for the estimation of glibenclamide in pure form and in dosage form. IJPSR 2014;5:4925-8.

14. Attia KAM, Elabasawy NM, Abolmagd E. Simultaneous equation and area under curve spectrophotometric methods for estimation of cefaclor; in presence of its acid induced degradation product. Future J Pharm Sci 2017;30:1-5.

15. Ilango K, Kumar SPS. Simultaneous determination of olmesartan medoxomil and hydrochlorothiazide by area under curve and dual wavelength spectrophotometric methods. J Pharm Sci Res 2012;4:1946-9.

16. Karajgi SR, Tanveer AR, Kalyane NV. Simultaneous determination of artemether and lumefantrine by area under curve U. V. spectrophotometric method. J Pharm Sci Res 2016;8:506-11.

17. Nasution LR, Bachri M, Putra EDL. Simultaneous estimation of isoniazid and pyridoxine hydrochloride in tablet dosage form by spectrophotometry ultraviolet with area under curve method. AJCPR 2018;11:124-6.

18. Zainuddin M. Application of multiple wavelength method in spectrophotometric multicomponent analysis of a mixture of phenylbutazone and methampyrone. Ind Pharm Mag 1999;10:217-28.

19. U.S. Food and drug administration, analytical procedures, and methods validation for drugs and biologics; 2015. Available from: http://www.fda.gov/BiologicsBloodVaccines/GuidanceComplian ceRegulatoryInformation/Guidances/default.htm [Last accessed on 05 Apr 2019]

20. Ermer J, Miller JH. Method validation in pharmaceutical analysis. A guide to best practice. Weinheim: Wiley-Vch Verlag GmBH and Co. KGaA; 2005. p. 171.

21. Harmita F. Implementation guidelines for method validation and method of calculation. Ind Pharm Mag Jakarta 2004;1:18-20. 